\title{
Liver function following hepatitis $C$ virus eradication by direct acting antivirals in patients with liver cirrhosis: data from the PITER cohort
}

Maria Giovanna Quaranta', Luigina Ferrigno' ${ }^{1}$ Xhimi Tata², Franca D’Angelo ${ }^{1}$, Carmine Coppola ${ }^{3}$, Alessia Ciancio ${ }^{4}$, Serena Rita Bruno ${ }^{5}$, Martina Loi ${ }^{6}$, Alessia Giorgini ${ }^{7}$, Marzia Margotti ${ }^{8}$, Valentina Cossiga ${ }^{9}$, Giuseppina Brancaccio ${ }^{10}$, Marcello Dallio ${ }^{11}$, Martina De Siena ${ }^{12}$, Marco Cannizzaro ${ }^{13}$, Luisa Cavalletto ${ }^{14}$, Marco Massari ${ }^{15}$, Maria Mazzitelli ${ }^{16}$, Pasqualina De Leo ${ }^{17}$, Diletta Laccabue ${ }^{18}$, Leonardo Baiocchi ${ }^{19}$ and Loreta A. Kondilii ${ }^{*}$

\begin{abstract}
Background: The development of direct-acting antivirals (DAA) for HCV has revolutionized the treatment of HCV, including its treatment in patients with HIV coinfection. The aim of this study was to compare the changes in liver function between coinfected and monoinfected patients with cirrhosis who achieved HCV eradication by DAA.
\end{abstract}

Methods: Patients with pre-treatment diagnosis of HCV liver cirrhosis, consecutively enrolled in the multicenter PITE $R$ cohort, who achieved a sustained virological response 12 weeks after treatment cessation (SVR12) were analysed. Changes in Child-Pugh (C-P) class and the occurrence of a decompensating event was prospectively evaluated after the end of DAA treatment. Cox regression analysis was used to evaluate factors independently associated with changes in liver function following viral eradication.

Results: We evaluated 1350 patients, of whom 1242 HCV monoinfected (median follow-up 24.7, range 6.8-47.5 months after viral eradication) and 108 (8\%) HCV/HIV coinfected (median follow-up 27.1, range 6.0-44.6).

After adjusting for age, sex, HCV-genotype, HBsAg positivity and alcohol use, HIV was independently associated with a more advanced liver disease before treatment (C-P class B/C vs A) (OR: 3.73, 95\% Cl:2.00-6.98). Following HCV eradication, C-P class improved in 17/20 (85\%) coinfected patients (from B to A and from C to B) and in 53/82 (64.6\%) monoinfected patients (from B to A) $(p=0.08)$. C-P class worsened in $3 / 56$ coinfected (5.3\%) (from A to B) and in $84 / 1024$ (8.2\%) monoinfected patients ( $p=0.45$ ) (from $A$ to $B$ or $C$ and from $B$ to $C$ ).

Baseline factors independently associated with C-P class worsening were male sex $(\mathrm{HR}=2.00 ; 95 \% \mathrm{Cl}=1.18-3.36)$,

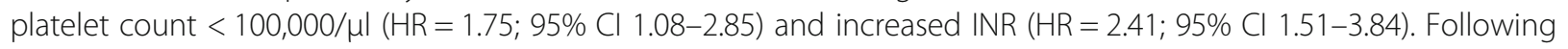
viral eradication, in 7 of 15 coinfected (46.6\%) and in 61 of 133 (45.8\%) monoinfected patients with previous history of decompensation, a new decompensating event occurred. A first decompensating event was recorded in 4 of 93 (Continued on next page)

\footnotetext{
* Correspondence: loreta.kondili@iss.it

'Center for Global Health, Istituto Superiore di Sanità, Viale Regina Elena 299, 00161 Rome, Italy

Full list of author information is available at the end of the article
}

C C The Author(s). 2021 Open Access This article is licensed under a Creative Commons Attribution 4.0 International License, which permits use, sharing, adaptation, distribution and reproduction in any medium or format, as long as you give appropriate credit to the original author(s) and the source, provide a link to the Creative Commons licence, and indicate if changes were made. The images or other third party material in this article are included in the article's Creative Commons licence, unless indicated otherwise in a credit line to the material. If material is not included in the article's Creative Commons licence and your intended use is not permitted by statutory regulation or exceeds the permitted use, you will need to obtain permission directly from the copyright holder. To view a copy of this licence, visit http://creativecommons.org/licenses/by/4.0/ The Creative Commons Public Domain Dedication waiver (http://creativecommons.org/publicdomain/zero/1.0/) applies to the data made available in this article, unless otherwise stated in a credit line to the data. 
(Continued from previous page)

(4.3\%) coinfected and in 53 of 1109 (4.8\%) monoinfected patients ( $p=0.83$ ).

Conclusions: Improvement of liver function was observed following HCV eradication in the majority of patients with cirrhosis; however viral eradication did not always mean cure of liver disease in both monoinfected and coinfected patients with advanced liver disease.

Keywords: Hepatitis C virus, Human immunodeficiency virus, Real-life cohort, Direct-acting antivirals, Advanced liver disease, Decompensated cirrhosis

\section{Background}

Hepatitis C Virus (HCV) eradication by direct-acting antivirals (DAA) is linked to improved outcomes at all stages of liver disease [1]. Available data suggest that the maximum efficacy and benefits are obtained by treating patients before they reach the stage of advanced fibrosis or cirrhosis [2, 3]. Sustained virologic response (SVR) reduces the risk of liver decompensation and of hepatocellular carcinoma (HCC) and improves survival [1, 4, 5]. However, a "point of non-return" in terms of deterioration of liver function, has been observed in part of patients regardless of viral eradication, potentially due to the pretreatment severe liver fibrosis and/or presence of other cofactors of liver disease progression $[3,4,6]$. As a cofactor, Human Immunodeficiency Virus (HIV) coinfection negatively affect the natural course of chronic HCV infection. Patients have a faster progression of liver fibrosis, an earlier transition to cirrhosis, a higher risk of hepatic decompensation and occurrence of HCC compared with HCVmonoinfected patients as well as a potential toxicity of antiretroviral therapy in the liver [7-12].

The development of DAA against $\mathrm{HCV}$ has revolutionized the treatment of hepatitis $\mathrm{C}$, including its treatment in patients with HIV coinfection, which have resulted with similar SVR rates as those of HCV monoinfected patients, shorter and simpler regimens with minimal treatmentrelated side effects compared with previous Interferon (IFN)-based therapies [13-17]. However, for HIV/HCVcoinfected patients with cirrhosis, the potential benefits of viral eradication could be counterbalanced by a poorer recovery of liver function. A critical issue for both monoinfected and coinfected patients that eradicate $\mathrm{HCV}$ infection in the cirrhosis stage of liver disease is the occurrence or deterioration of liver-related clinical events.

The aim of this study was to assess the liver disease outcomes after viral eradication in terms of changes in ChildPugh (C-P) class and the occurrence of a decompensating event, in a real-life cohort of patients with advanced liver disease due to HCV infection with or without HIV coinfection.

\section{Methods}

\section{Patients}

Patients were recruited from the Italian Platform for the study of viral hepatitis therapy (PITER) cohort between
April 2015 and June 2019. PITER is a prospective multicentric cohort, considered representative of patients with chronic HCV infection in care in Italy. Patients have been consecutively enrolled in certain periods of time yearly and were not receiving $\mathrm{HCV}$ treatment at the time of inclusion in the cohort [18]. In this study, HCV/HIV coinfected patients and HCV monoinfected patients with known HIV negative status, with pre-treatment diagnosis of liver cirrhosis who had achieved a SVR 12 weeks after DAA treatment cessation (SVR12) were included. Patients with a history of liver transplantation prior to treatment were excluded. Patients' data prior to the treatment start were considered as baseline. Patients' data during the follow-up after the end of treatment were prospectively evaluated. Viral eradication was defined as undetectable HCV-RNA level, as assessed by highly sensitive molecular methods (lower limit of detection ranging from $\leq 12$ to $\leq 15 \mathrm{IU} / \mathrm{ml}$ ), at the end of treatment and at the 12-week post-treatment evaluation.

Fibrosis stage was defined based on liver transient elastography data, which were considered as validated if each patient had at least 10 valid stiffness measurements, with a success rate of at least $80 \%$, an interquartile range of less than $30 \%$ of the median stiffness score, and a body mass index (BMI) of $<30 \mathrm{~kg} / \mathrm{m}^{2}$ [19]. Liver cirrhosis was defined when the stiffness score was equal to or higher than $12.5 \mathrm{kPa}$ or according to biochemical and instrumental data of portal hypertension [20].

\section{Outcome variables}

Clinical outcomes evaluated included the occurrence of a decompensating event (ascites and/or gastrointestinal bleeding due to portal hypertension and/or hepatic encephalopathy) and changes in the severity of liver disease in terms of C-P class worsening or improvement whatever occurred first during the follow-up after the end of treatment.

\section{Statistical analysis}

Patient's main baseline characteristics were reported as median and interquartile range (IQR) or as proportions [number (N) and percentage (\%)] for continuous and categorical variables, respectively. The Mann-Whitney U test was used for continuous variables to assess 
differences between distribution, and the Chi-squared test was used for comparisons of proportions. A $p$-value of $<0.05$ was considered statistically significant.

A multiple logistic regression analysis was performed using C-P class prior to antiviral treatment as the dependent variable and the following variables at baseline as covariates: age, sex, HCV genotype, HBsAg positivity, alcohol use and HIV coinfection.

Variables independently associated with worsening of liver function, as determined by changes in C-P class after the end of treatment, were evaluated by Cox proportional hazard models. All analyses were performed using the STATA/SE 15.1 statistical package (StataCorp LP, College Station, TX, USA).

\section{Results}

Baseline characteristics of patients

A total of $108 \mathrm{HIV} / \mathrm{HCV}$ coinfected (81.5\% males) and $1242 \mathrm{HCV}$ monoinfected patients (58.1\% males) were considered in the present analyses. Baseline characteristics of these patients are summarised in Table 1.

Coinfected patients were significantly younger (median age of 52.5 vs 64 years, $p<0.001$ ) and compared with monoinfected patients had significantly lower BMI $(p<0.001)$. Current alcohol use is more frequently reported in coinfected compared with monoinfected patients $(p<0.001)$.

A significantly different distribution in HCV genotypes in monoinfected compared with coinfected patients was observed. About half of the monoinfected patients $(n=665,53.5 \%)$ were infected by HCV genotype $1 \mathrm{~b}$, whereas genotype $1 \mathrm{a}$ and 3 were prevalent in coinfected patients $(n=33,30.6 \%$ and $n=31,28.7 \%$, respectively) $(p<0.001)$.

Higher prevalence of anti-HBc+/HBsAg- $(43.5 \%$ vs $21.1 \%)$ and anti-HBc+/HBsAg+ (3.7\% vs $1.2 \%, p<0.001)$ was detected in coinfected compared with monoinfected patients $(p<0.001)$.

A significant difference in the prevalence of HCC between coinfected and monoinfected patients was observed ( $0.9 \%$ vs $6.3 \%$, respectively; $p=0.02)$.

Before starting therapy, 15 (13.9\%) co-infected and 133 (10.7\%) monoinfected patients had reported a previous liver decompensating event $(p=0.31)$.

Coinfected patients had a more severe liver disease in terms of C-P class distribution (A5: $52.7 \%$ vs 69.5\%; A6: $18.9 \%$ vs $22.1 \%$; B7: $16.2 \%$ vs $5.3 \%$; B8: $10.8 \%$ vs $2.6 \%)$, compared with monoinfected patients $(p<0.001)$.

After adjusting for potential factors of liver disease severity before treatment, such as age, sex, HCV genotype, HBsAg positivity, alcohol use and HIV coinfection, HIV was the only factor independently associated [Odds
Ratios (OR): 3.73, 95\% Confidence Interval (CI): 2.006.98] with C-P class $\mathrm{B} / \mathrm{C}$ vs A (Table 2).

\section{Prospective evaluation on changes in liver function after viral eradication}

Coinfected and monoinfected patients were evaluated during a median follow-up of 27.1 (range 6.0-44.6) and 24.7 (range 6.8-47.5) months after viral eradication, respectively. Changes in the severity of liver disease in terms of C-P class worsening or improvement are shown in Fig. 1.

During the follow-up C-P class improved in 17/20 (85\%) coinfected patients (of whom 16 from C-P class B to $A$ and 1 from $C-P$ class $C$ to $B$ ) and in $53 / 82(64.6 \%)$ monoinfected patients (from C-P class B to A) $(p=$ $0.08)$. C-P class worsened in $3 / 56$ (5.3\%) coinfected patients (from C-P class A to B) and in 84/1024 (8.2\%) $\mathrm{HCV}$-monoinfected patients (of whom 79 from C-P class A to $\mathrm{B}, 4$ from $\mathrm{C}-\mathrm{P}$ class $\mathrm{B}$ to $\mathrm{C}$ and 1 from $\mathrm{C}-\mathrm{P}$ class $\mathrm{A}$ to $\mathrm{C})(p=0.45)$.

No difference in the occurrence of a decompensating event following viral eradication was observed between coinfected $(n=11,10.2 \%)$ and monoinfected $(n=114$, 9.2\%) $(p=0.73)$ patients. Of patients with decompensated cirrhosis prior to therapy in 7 of $15(46.6 \%)$ coinfected and in 61 of 133 (45.8\%) monoinfected patients a new decompensating event occurred following viral eradication. A total of 4 of $93(4.3 \%)$ coinfected and 53 of $1109(4.8 \%)(p=0.83)$ monoinfected patients had their first decompensating event. Decompensating events recorded after viral eradication in both patients with or without a previous history of decompensation were mainly represented by the presence of ascites, however encephalopathy and variceal bleeding were also present (Table 3).

\section{Baseline predictors of Child-Pugh class worsening after viral eradication}

Male sex [Hazard ratio (HR) $=1.77$; 95\% CI: 1.12-2.81], platelet count lower than $100,000 / \mu \mathrm{L}(\mathrm{HR}=2.01 ; 95 \%$ CI: $1.31-3.08)$, increased international normalized ratio (INR) $\quad(\mathrm{HR}=2.15 ; 95 \%$ CI: $1.45-3.19)$, presence of esophageal varices $(\mathrm{HR}=1.85$; $95 \% \mathrm{CI}: 1.20-2.85)$, history of HCC (HR $=2.32 ; 95 \% \mathrm{CI}: 1.20-4.49)$ and history of decompensation ( $\mathrm{HR}=1.97$; 95\% CI: $1.17-3.31)$ were significantly associated with C-P class worsening at univariate analysis. At multivariate analysis, male sex $(\mathrm{HR}=$ 2.00; 95\% CI: $1.18-3.36$ ), platelet count lower than 100 , $000 / \mu \mathrm{L}(\mathrm{HR}=1.75 ; 95 \% \mathrm{CI}: 1.08-2.85)$ and increased INR (HR $=2.41 ; 95 \% \mathrm{CI}: 1.51-3.84)$ resulted independently associated with C-P class worsening. HIV coinfection was not associated with the C-P class worsening both at univariate and at multivariate analysis (Table 4). 
Table 1 - Baseline characteristics of cirrhotic patients

\begin{tabular}{|c|c|c|c|c|c|c|}
\hline \multirow{2}{*}{\multicolumn{2}{|c|}{ Quantitative variables }} & \multicolumn{2}{|c|}{ HCV/HIV co-infected $\left(N=108^{*}\right)$} & \multicolumn{3}{|c|}{ HCV mono-infected $\left(N=1242^{*}\right)$} \\
\hline & & Median & IQR & Median & IQR & $p^{* *}$ \\
\hline \multicolumn{2}{|l|}{ Age (years) } & 52.5 & $50-55$ & 64.0 & $54-72$ & $<0.001$ \\
\hline \multicolumn{2}{|l|}{$\mathrm{ALT}(\mathrm{IU} / \mathrm{L})$} & 63.0 & $40.0-91.0$ & 74.0 & $47.0-115.0$ & 0.01 \\
\hline \multicolumn{2}{|l|}{ AST (IU/L) } & 60.0 & $44.0-95.0$ & 70.0 & $47.0-105.0$ & 0.14 \\
\hline \multicolumn{2}{|l|}{ Platelets/ $\mu \mathrm{L}$} & 105,000 & $74,000-154,000$ & 119,000 & $86,350-159,000$ & 0.06 \\
\hline \multicolumn{2}{|l|}{ Albumin $(\mathrm{g} / \mathrm{dL})$} & 3.9 & $3.5-4.2$ & 3.9 & $3.6-4.2$ & 0.48 \\
\hline \multicolumn{2}{|l|}{ Bilirubin (mg/dL) } & 0.8 & $0.6-1.3$ & 0.9 & $0.6-1.1$ & 0.54 \\
\hline \multicolumn{2}{|l|}{ INR } & 1.1 & $1.0-1.2$ & 1.1 & $1.0-1.2$ & 0.10 \\
\hline \multicolumn{2}{|c|}{ Categorical variables } & N. & $\%$ & N. & $\%$ & $p^{* * *}$ \\
\hline \multirow[t]{2}{*}{ Sex } & Male & 88 & 81.5 & 722 & 58.1 & $<0.001$ \\
\hline & Female & 20 & 18.5 & 520 & 41.9 & \\
\hline \multirow[t]{4}{*}{$\mathrm{BMI}$} & Underweight & 5 & 4.6 & 14 & 1.1 & $<0.001$ \\
\hline & Normal & 70 & 64.8 & 514 & 41.4 & \\
\hline & Overweight & 25 & 23.2 & 550 & 44.3 & \\
\hline & Obese & 8 & 7.4 & 163 & 13.1 & \\
\hline \multirow[t]{3}{*}{ Alcohol use } & Never & 50 & 52.1 & 803 & 66.0 & $<0.001$ \\
\hline & Current & 26 & 27.1 & 116 & 9.5 & \\
\hline & Past & 20 & 20.8 & 297 & 24.4 & \\
\hline \multirow{7}{*}{$\begin{array}{l}\text { HCV- } \\
\text { genotype }\end{array}$} & 1 (Non subtyped) & 5 & 4.6 & 36 & 2.9 & $<0.001$ \\
\hline & $1 a$ & 33 & 30.6 & 170 & 13.7 & \\
\hline & $1 b$ & 15 & 13.9 & 665 & 53.5 & \\
\hline & 2 & 4 & 3.7 & 168 & 13.5 & \\
\hline & 3 & 31 & 28.7 & 120 & 9.7 & \\
\hline & 4 & 20 & 18.5 & 83 & 6.7 & \\
\hline & 5 & 0 & 0.0 & 0 & 0.0 & \\
\hline \multirow[t]{2}{*}{ Diabetes } & Yes & 16 & 14.8 & 259 & 20.9 & 0.14 \\
\hline & No & 92 & 85.2 & 983 & 79.2 & \\
\hline \multirow{3}{*}{$\begin{array}{l}\text { HBV } \\
\text { Infection }\end{array}$} & Anti-HBC+/HBsAg+ & 4 & 3.7 & 15 & 1.2 & $<0.001$ \\
\hline & Anti-HBC+/HBsAg- & 47 & 43.5 & 262 & 21.1 & \\
\hline & No & 57 & 52.8 & 965 & 77.7 & \\
\hline \multirow{2}{*}{$\begin{array}{l}\text { Previous } \\
\text { Interferon }\end{array}$} & Yes & 30 & 27.8 & 415 & 33.4 & 0.23 \\
\hline & No & 78 & 72.2 & 827 & 66.6 & \\
\hline \multirow[t]{2}{*}{$\mathrm{HCC}$} & Yes & 1 & 0.9 & 78 & 6.3 & 0.02 \\
\hline & No & 107 & 99.1 & 1164 & 93.7 & \\
\hline \multirow{2}{*}{$\begin{array}{l}\text { Esophageal } \\
\text { varices }\end{array}$} & Yes & 18 & 16.7 & 270 & 21.7 & 0.22 \\
\hline & No & 90 & 83.3 & 972 & 78.3 & \\
\hline \multirow[t]{2}{*}{ Ascites } & Yes & 10 & 9.3 & 81 & 6.5 & 0.28 \\
\hline & No & 98 & 90.7 & 1161 & 93.5 & \\
\hline \multirow{2}{*}{$\begin{array}{l}\text { Previous } \\
\text { decompensation }\end{array}$} & Yes & 15 & 13.9 & 133 & 10.7 & 0.31 \\
\hline & No & 93 & 86.1 & 1109 & 89.3 & \\
\hline \multirow{4}{*}{$\begin{array}{l}\text { Child-Pugh } \\
\text { Score }\end{array}$} & $A-5$ & 39 & 52.7 & 762 & 69.5 & $<0.001$ \\
\hline & $A-6$ & 14 & 18.9 & 242 & 22.1 & \\
\hline & $B-7$ & 12 & 16.2 & 58 & 5.3 & \\
\hline & B-8 & 8 & 10.8 & 28 & 2.6 & \\
\hline
\end{tabular}


Table 1 - Baseline characteristics of cirrhotic patients (Continued)

\begin{tabular}{clllc}
\hline & HCV/HIV co-infected $(\boldsymbol{N}=\mathbf{1 0 8 *})$ & \multicolumn{2}{l}{ HCV mono-infected $(\boldsymbol{N}=\mathbf{1 2 4 2})$} \\
\hline B-9 & 0 & 0.0 & 6 & 0.6 \\
C-10 & 1 & 1.4 & 0 & 0.0 \\
\hline
\end{tabular}

*For some variables inconsistencies are due to missing values

** $p$ value Mann-Whitney rank-sum test

*** $p$ value Chi-square test

\section{Discussion}

This is one of a few multicentric cohort studies, representative of patients with chronic $\mathrm{HCV}$ infection in care in Italy that prospectively evaluated the medium-term outcomes following $\mathrm{HCV}$ eradication by DAA in consecutively enrolled patients with severe liver disease, based on HIV status. Regarding the HIV coinfection in our study population, HIV coinfected patients were at least 10 years younger than HCV monoinfected patients. This age difference potentially reflect the epidemiology of HIV infection mainly related with a later epidemic wave compared with the post transfusion and nosocomial epidemic wave of HCV monoinfection in Italy [21]. We found younger age, a higher prevalence of genotype 3 , past or current alcohol abuse and HBV coinfection in HIV coinfected compared with $\mathrm{HCV}$ monoinfected patients. All these factors are known cofactors for liver disease progression [22-24] and could explain the more advanced liver cirrhosis in coinfected compared with monoinfected patients. However, after adjusting for all the above mentioned factors, only HIV coinfection was found independently associated with more severe liver damage before treatment. Based on this finding, our study could confirm that despite the younger age, coinfected patients have significantly more advanced liver cirrhosis compared with monoinfected patients. On the contrary, the possible longer time of infection and longer duration of cirrhosis, considering as surrogate marker of this the older age of monoinfected patients, could explain the higher HCC prevalence in monoinfected compared with coinfected patients prior to therapy [22].

Regarding the effectiveness of the DAA therapy we evaluated the liver disease related outcomes following the successful therapy according to HIV status. Previous

Table 2 - Baseline factors associated with Child-Pugh class (A vs B/C). Multivariate analysis

\begin{tabular}{lll}
\hline Baseline factors & Adjusted O.R. & $\mathbf{9 5 \% ~ C l}$ \\
\hline Age (increasing years) & 1.00 & $0.98-1.02$ \\
Sex (ref. female) & 1.07 & $0.69-1.67$ \\
Current/past alcohol use (ref. never) & 0.87 & $0.56-1.37$ \\
HCV-genotype (3 vs others) & 1.48 & $0.80-2.76$ \\
HBsAg+ & 2.27 & $0.57-8.99$ \\
HIV+ & $\mathbf{3 . 7 3}$ & $\mathbf{2 . 0 0 - 6 . 9 8}$ \\
\hline
\end{tabular}




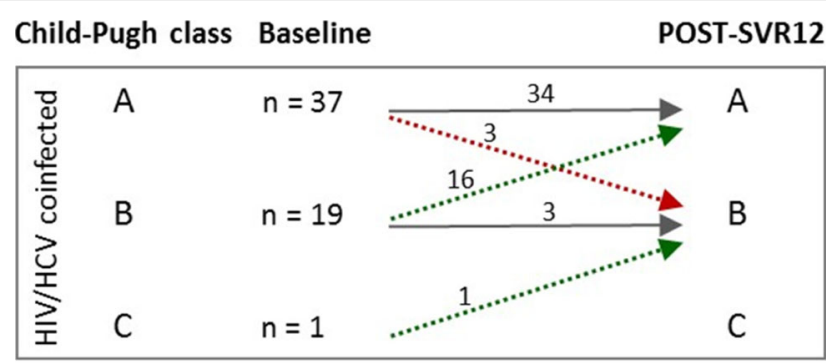

Child-Pugh class changes

AA 34/37 (92\%)

$A B$ 3/37 (8.1\%)

BA $16 / 19$ (84.2\%)

BB 3/19 (15.8\%)

CB 1/1 (100\%)

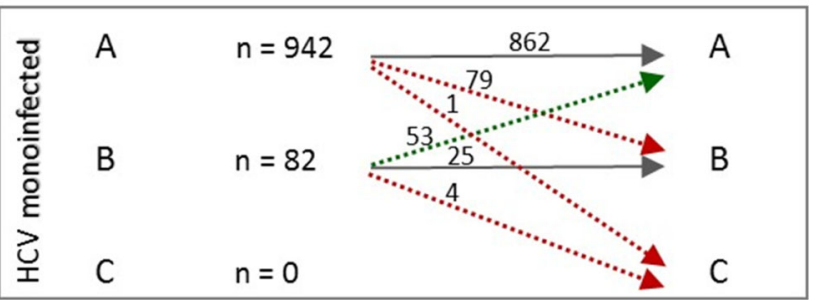

AA 862/942 (91.5\%)

AB 79/942 (8.4\%)

AC $1 / 942(0.1 \%)$

BA $53 / 82(64.6 \%)$

BB 25/82 (30.5\%)

BC $4 / 82$ (4.8\%)

Fig. 1 Changes in the severity of liver disease in terms of C-P class improvement or worsening in monoinfected and coinfected patients

coinfection was not an independent factor of liver disease worsening. In previous studies, additional analyses have suggested that patients above 65 years of age with reduced hepatic synthetic function were less likely to benefit from DAA therapy, however these factors were not sufficiently discriminative to identify a subgroup in which antiviral therapy should be deferred in favour of liver transplant [5].

Regarding the appearance of a decompensating event following viral eradication, we found that 11 coinfected patients (10.2\%) and 114 monoinfected patients (9.2\%) had a new decompensating event. These results were slightly higher compared with previous data that reported the appearance of a new decompensating event in $7.5 \%$ of patients [34]. Different liver disease severity prior to viral eradication could explain these differences $[1,6,34,35]$. A total of $46.6 \%$ of coinfected and $45.8 \%$ of monoinfected patients with a history of hepatic decompensation before treatment start, maintained the risk of cirrhosis progression to decompensation after viral eradication. Our data were confirmed by another study that found about $36 \%$ of patients with severe portal hypertension remaining at high risk for decompensation [36]. Different risks in patients with different baseline characteristics have been indicated $[1,6]$, however there are lack of data in the literature regarding the rate of a

Table 3 Occurrence of decompensating event following viral eradication

\begin{tabular}{|c|c|c|c|c|}
\hline \multirow[b]{2}{*}{ Patients with a pre-treatment history of decompensated cirrhosis } & \multicolumn{2}{|c|}{ HCV/HIV co-infected $(N=11)$} & \multicolumn{2}{|c|}{ HCV mono-infected $(N=114)$} \\
\hline & N. & $\%$ & N. & $\%$ \\
\hline Ascites & 6 & 85.7 & 32 & 52.5 \\
\hline Ascites + hepatic encephalopathy & 0 & 0.0 & 8 & 13.1 \\
\hline Ascites + gastrointestinal bleeding & 0 & 0.0 & 2 & 3.3 \\
\hline Ascites + gastrointestinal bleeding + hepatic encephalopathy & 0 & 0.0 & 2 & 3.3 \\
\hline Hepatic encephalopathy & 0 & 0.0 & 9 & 14.8 \\
\hline Gastrointestinal bleeding & 1 & 14.3 & 8 & 13.1 \\
\hline TOTAL & 7 & 100.0 & 61 & 100.0 \\
\hline Patients with incident decompensating event & N. & $\%$ & N. & $\%$ \\
\hline Ascites & 3 & 75.0 & 32 & 67.9 \\
\hline Ascites + hepatic encephalopathy & 0 & 0.0 & 6 & 3.8 \\
\hline Hepatic encephalopathy & 1 & 25.0 & 6 & 11.3 \\
\hline Gastrointestinal bleeding & 0 & 0.0 & 9 & 17.0 \\
\hline TOTAL & 4 & 100.0 & 53 & 100.0 \\
\hline
\end{tabular}


Table 4 - Baseline factors associated with Child-Pugh class worsening following viral eradication. Univariate and multivariate analysis

\begin{tabular}{|c|c|c|c|c|}
\hline Baseline factors & Crude HR & $95 \% \mathrm{Cl}$ & Adjusted HR & $95 \% \mathrm{Cl}$ \\
\hline HIV infection & 0.68 & $0.21-2.15$ & 0.51 & $0.15-1.73$ \\
\hline Age (increasing years) & 1.00 & $0.98-1.02$ & 1.00 & $0.98-1.02$ \\
\hline Sex (ref. female) & 1.77 & $1.12-2.81$ & 2.00 & $1.18-3.36$ \\
\hline BMI: overweight/obese (ref. under-normalweight) & 0.88 & $0.58-1.34$ & 0.79 & $0.51-1.22$ \\
\hline Current/past alcohol use (ref. never) & 0.99 & $0.63-1.55$ & 0.76 & $0.47-1.24$ \\
\hline ALT (increasing IU/L) & 1.00 & $0.99-1.00$ & 1.00 & $0.99-1.01$ \\
\hline AST (increasing IU/L) & 1.00 & $0.99-1.00$ & 0.99 & $0.98-1.00$ \\
\hline Platelets (ref. > 100,000/ $\mu \mathrm{L}$ ) & 2.01 & $1.31-3.08$ & 1.75 & $1.08-2.85$ \\
\hline Albumin (decreasing g/dL) & 1.57 & $0.99-2.43$ & 1.35 & $0.82-2.23$ \\
\hline Bilirubin (increasing mg/dL) & 0.98 & $0.87-1.12$ & 0.84 & $0.60-1.18$ \\
\hline INR (increasing unit) & 2.15 & $1.45-3.19$ & 2.41 & $1.51-3.84$ \\
\hline HCV-genotype (3 vs others) & 1.51 & $0.80-2.84$ & 1.54 & $0.75-3.17$ \\
\hline Diabetes & 1.14 & $0.69-1.89$ & 0.93 & $0.55-1.57$ \\
\hline Anti-HBC+ & 1.02 & $0.63-1.65$ & 1.05 & $0.63-1.76$ \\
\hline Previous Interferon treatment & 0.82 & $0.52-1.29$ & 0.77 & $0.48-1.23$ \\
\hline Esophageal varices & 1.85 & $1.20-2.85$ & 1.47 & $0.89-2.42$ \\
\hline $\mathrm{HCC}$ & 2.32 & $1.20-4.49$ & 1.88 & $0.87-4.08$ \\
\hline Previous decompensating event & 1.97 & $1.17-3.31$ & 1.12 & $0.60-2.11$ \\
\hline
\end{tabular}

first decompensating event following viral eradication. In this study a first decompensating event, in patients without a previous liver decompensation, was observed in $4.3 \%$ coinfected and in $4.8 \%$ monoinfected patients. A recent study reported a lower incidence of liver decompensation $(0.9 \%)$, but the small sample size could justify the difference with our data [37].

Regarding the HCC occurrence, a similar cumulative HCC incidence in coinfected $(2.2 \%)$ and monoinfected $(3.9 \%)(p=0.38)$ patients after viral eradication, was reported in our recent study, suggesting that HIV coinfection is not associated with a higher probability of developing liver complications in successfully DAA treated patients with compensated cirrhosis [3].

Our findings confirm the existence of a point of no return, after which antiviral treatment may be too late to influence the natural history of HCV liver related disease, however more data are needed to better define this patient's population.

\section{Conclusion}

Viral eradication after DAA therapy represents a positive prognostic factor of liver function improvement, in particular in terms of C-P class. However, during a medium time of more than 2 years following the SVR achieved after the DAA treatment, this benefit was not extended in almost $10 \%$ of patients in whom liver disease progression continues regardless of viral eradication in both $\mathrm{HCV}$ monoinfected and $\mathrm{HCV} / \mathrm{HIV}$ coinfected patients.

\section{Abbreviations}

BMI: Body mass index; Cl: Confidence interval; C-P class: Child-Pugh class; DAA: Direct-acting antivirals; HCC: Hepatocellular carcinoma; HCV: Hepatitis C virus; HIV: Human Immunodeficiency Virus; HR: Hazard ratio; IFN: Interferon; INR: International normalized ratio; IQR: Interquartile range; OR: Odds ratios; PITER: Italian Platform for the study of viral hepatitis therapy; SVR: Sustained virologic response; SVR12: Sustained virologic response 12 weeks after treatment cessation

\section{Supplementary Information}

The online version contains supplementary material available at https://doi. org/10.1186/s12879-021-06053-3.

\section{Additional file 1}

\section{Acknowledgements}

Authors wish to thank PITER collaborating group and all clinical centres (listed in the Supplement) which are involved in the study on a voluntary basis and Giampaolo La Terza (Medisoft Informatic Services) for Database maintenance and implementation.

\section{Authors' contributions}

Conceptualization: L.A.K. Formal analysis and investigation: L.A.K, M.G.Q. Writing - original draft preparation: L.A.K., M.G.Q. Data curation: M.G.Q., L.F., F.D. Resources: X.T., C.C., A.C., S.R.B., M.L., A.G., M.Mar., V.C., G.B., M.D., M.D., M.C., L.C., M.Mas., M.Maz., P.D., D.L., L.B. Supervision: L.A.K. All the authors have read and approved the final manuscript.

\section{Funding}

This study was funded by Italian Ministry of Health, Grant number RF-201602364053

\section{Availability of data and materials}

The datasets used and/or analysed during the current study are available from the corresponding author on reasonable request. 


\section{Declarations}

\section{Ethics approval and consent to participate}

The study was conducted in accordance with the guidelines of the Declaration of Helsinki and the principles of Good Clinical Practice. The study protocol was approved by the Ethics Committee of the Istituto Superiore di Sanità (Italian National Institute of Public Health) and by the local Ethics committees of each clinical center. The patients' data were evaluated through an anonymous analysis, adopting codes generated by the electronic case report forms. All patients gave their written informed consent to participate in the study.

\section{Consent for publication}

Not applicable.

\section{Competing interests}

All authors declare no conflicts of interest regarding the present study.

\section{Author details}

${ }^{1}$ Center for Global Health, Istituto Superiore di Sanità, Viale Regina Elena 299, 00161 Rome, Italy. ${ }^{2}$ University of Tor Vergata, Nostra Signora del Buon Consiglio di Tirana, Tirana, Albania. ${ }^{3}$ Department of Hepatology, Gragnano Hospital, Naples, Italy. ${ }^{4}$ Gastroenterology Unit, University of Turin, Turin, Italy. ${ }^{5}$ Infectious Diseases, Ospedali Riuniti, Foggia, Italy. ${ }^{6}$ Liver Unit, University Hospital, Monserrato, Cagliari, Italy. 'Department of Health Sciences, San Paolo Hospital, University of Milan, Milan, Italy. ${ }^{8}$ Department of Internal Medicine, University Hospital of Modena, Modena, Italy. ${ }^{9}$ Department of Clinical Medicine and Surgery, Federico II University, Naples, Italy.

${ }^{10}$ Department of Infectious Disease, University of Padua, Padua, Italy.

${ }^{11}$ Department of Precision Medicine, University of Campania Luigi Vanvitelli, Naples, Italy. ${ }^{12}$ Department of Internal Medicine and Gastroenterology, Fondazione Policlinico A. Gemelli IRCCS, Università Cattolica del Sacro Cuore, Rome, Italy. ${ }^{13}$ Internal Medicine, Villa Sofia-Cervello Hospital, Palermo, Italy.

${ }^{14}$ Department of Medicine, University Hospital of Padua, Padua, Italy.

${ }^{15}$ Infectious Diseases, Azienda Unità Sanitaria Locale - IRCCS di Reggio Emilia, Reggio Emilia, Italy. ${ }^{16}$ Department of Infectious Disease, University Hospital Mater Domini, Catanzaro, Italy. ${ }^{17}$ Department of Infectious Disease, San Paolo Hospital, Savona, Italy. ${ }^{18}$ Unit of Infectious Diseases and Hepatology, Azienda Ospedaliero-Universitaria di Parma, Parma, Italy. ${ }^{19}$ Department of Medical Sciences, University of Tor Vergata, Rome, Italy.

\section{Received: 21 December 2020 Accepted: 6 April 2021}

\section{Published online: 04 May 2021}

\section{References}

1. Carrat F, Fontaine H, Dorival C, Simony M, Diallo A, Hezode C, et al. Clinical outcomes in patients with chronic hepatitis $\mathrm{C}$ after direct-acting antiviral treatment: a prospective cohort study. Lancet. 2019:393(10179):1453-64. https://doi.org/10.1016/S0140-6736(18)32111-1

2. Kondili LA, Gaeta GB, Brunetto MR, di Leo A, lannone A, Santantonio TA et al. Incidence of DAA failure and the clinical impact of retreatment in reallife patients treated in the advanced stage of liver disease: interim evaluations from the PITER network. PLoS One. 2017;12(10):e0185728. https://doi.org/10.1371/journal.pone.0185728.

3. Quaranta MG, Ferrigno L, Monti M, et al. PITER Collaborating Group. Advanced liver disease outcomes after hepatitis $C$ eradication by human immunodeficiency virus infection in PITER cohort. Hepatol Int. 2020;14:362-72.

4. Calvaruso V, Craxì A. Hepatic benefits of HCV cure. J Hepatol. 2020;73(6): 1548-56. https://doi.org/10.1016/j.jhep.2020.08.006.

5. van der Meer AJ, Berenguer M. Reversion of disease manifestations after HCV eradication. J Hepatol. 2016;65(1):S95-S108. https://doi.org/10.1016/j. jhep.2016.07.039.

6. Verna EC, Morelli G, Terrault NA, Lok AS, Limet JK, et al. DAA therapy and long-term hepatic function in advanced/decompensated cirrhosis: Realworld experience from HCV-TARGET cohort. J Hepatol. 2020; https://doi. org/10.1016/j.jhep.2020.03.031;73(3):540-8.

7. Rockstroh JK, Spengler U. HIV and hepatitis C virus coinfection. Lancet Infect Dis. 2004:4(7):437-4. https://doi.org/10.1016/\$1473-3099(04)01059-X.

8. Chen JY, Feeney ER, Chung RT. HCV and HIV co-infection: mechanisms and management. Nat Rev Gastroenterol Hepatol. 2014;11(6):362-71. https://doi. org/10.1038/nrgastro.2014.17.
9. Macías J, Márquez M, Téllez F, Merino D, Jiménez-Aguilar P, et al. Risk of liver decompensation among HIV/hepatitis C virus-coinfected individuals with advanced fibrosis: implications for the timing of therapy. Clin Infect Dis. 2013;57(10):1401-8. https://doi.org/10.1093/cid/cit537.

10. Merchante N, Merino E, López-Aldeguer J, Jover F, Delgado-Fernández M, Galindo MJ, et al. Increasing incidence of hepatocellular carcinoma in HIVinfected patients in Spain. Clin Infect Dis. 2013;56(1):143-50. https://doi. org/10.1093/cid/cis777.

11. Hernando V, Perez-Cachafeiro S, Lewden C, Gonzalez J, Segura F, Oteo JA, et al. All-cause and liver-related mortality in HIV positive subjects compared to the general population: differences by HCV co-infection. J Hepatol. 2012; 57(4):743-51. https://doi.org/10.1016/j.jhep.2012.06.010.

12. Pineda JA, Aguilar-Guisado M, Rivero A, Ruiz-Morales J, Merino D, RíosVillegas MJ, et al. Natural history of compensated hepatitis C virus-related cirrhosis in HIV-infected patients. Clin Infect Dis. 2009;49(8):1274-82. https:// doi.org/10.1086/605676.

13. Sulkowski MS, Gardiner DF, Rodriguez-Torres M, Reddy KR, Hassanein T, Jacobson I, et al. Daclatasvir plus sofosbuvir for previously treated or untreated chronic HCV infection. N Engl J Med. 2014;370(3):211-21. https:// doi.org/10.1056/NEJMoa1306218.

14. Afdhal N, Reddy KR, Nelson DR, Lawitz E, Gordon SC, Schiff E, et al. Ledipasvir and sofosbuvir for previously treated HCV genotype 1 infection. N Engl J Med. 2014;370(16):1483-93. https://doi.org/10.1056/NEJMoa1316366.

15. Meissner EG. Update in HIV/HCV co-infection in the direct acting antiviral era. Curr Opin Gastroenterol. 2017;33(3):120-7. https://doi.org/10.1097/MOG 0000000000000347

16. Giannini EG, Crespi M, Demarzo M, Bodini G, Furnari M, Marabotto E, et al Improvement in hepatitis $C$ virus patients with advanced, compensated liver disease after sustained virological response to direct acting antivirals. Eur J Clin Investig. 2019;49(3):e13056. https://doi.org/10.1111/eci.13056.

17. Piroth L, Wittkop L, Lacombe K, Rosenthal E, Gilbert C, Miailhes P, et al. Efficacy and safety of direct-acting antiviral regimens in HIV/HCV-co-infected patients - French ANRS CO13 HEPAVIH cohort. J Hepatol. 2017;67(1):23-31. https://doi.org/10.1016/j.jhep.2017.02.012.

18. Kondili LA, Vella S. PITER collaborating. PITER: an ongoing nationwide study on the real-life impact of direct acting antiviral based treatment for chronic hepatitis C in Italy. Dig Liver Dis. 2015;47(9):741-3. https://doi.org/10.1016/j. dld.2015.05.022

19. Ziol M, Handra-Luca A, Kettaneh A, Christidis C, Mal F, Kazemi F, et al. Noninvasive assessment of liver fibrosis by measurement of stiffness in patients with chronic hepatitis C. Hepatology. 2005;41(1):48-54. https://doi. org/10.1002/hep.20506.

20. Castéra L, Vergniol J, Foucher J, le Bail B, Chanteloup E, Haaser M, et al. Prospective comparison of transient elastography, Fibrotest, APRI, and liver biopsy for the assessment of fibrosis in chronic hepatitis C. Gastroenterology. 2005;128(2):343-50. https://doi.org/10.1053/j.gastro.2004.11.018.

21. Guadagnino V, Stroffolini T, Rapicetta M, Costantino A, Kondili LA, MennitiIppolito F, et al. Prevalence, risk factors, and genotype distribution of hepatitis $C$ virus infection in the general population: a community-based survey in southern Italy. Hepatology. 1997;26(4):1006-1. https://doi.org/10.1 002/hep.510260431.

22. Westbrook RH, Dusheiko G. Natural history of hepatitis C. J Hepatol. 2014; 61(1 Suppl):S58-68. https://doi.org/10.1016/j.jhep.2014.07.012 Epub 2014 Nov 3. PMID: 25443346.

23. Terrault NA, Hassanein TI. Management of the patient with SVR. J Hepatol. 2016;65(1 Suppl):S120-9. https://doi.org/10.1016/j.jhep.2016.08.001.

24. European Association for the Study of the Liver. EASL recommendations on treatment of hepatitis C 2018. J Hepatol. 2018:69:461-511.

25. Corma-Gómez A, Morano L, Téllez F, Rivero-Juárez A, Real LM, Alados JC, et al. HIV infection does not increase the risk of liver complications in hepatitis C virus-infected patient with advanced fibrosis, after sustained virological response with direct-acting antivirals. AIDS. 2019;33(7):1167-74. https://doi.org/10.1097/QAD.0000000000002186.

26. Macías J, Granados R, Téllez F, Merino D, Pérez M, Morano LE, et al. Similar recovery of liver function after response to all-oral HCV therapy in patients with cirrhosis with and without HIV coinfection. J Viral Hepat. 2019;26(1):1624. https://doi.org/10.1111/jvh.12990.

27. Lledó GM, Carrasco I, Benítez-Gutiérrez LM, Arias A, Royuela A, Requena S, et al. Regression of liver fibrosis after curing chronic hepatitis $C$ with oral antivirals in patients with and without HIV coinfection. AIDS. 2018;32(16): 2347-52. https://doi.org/10.1097/QAD.0000000000001966. 
28. El-Sherif O, Jiang ZG, Tapper EB, Huang KC, Zhong A, et al. Baseline factors associated with improvements in decompensated cirrhosis after directacting antiviral therapy for hepatitis C virus infection. Gastroenterology. 2018:154(8):2111-21. https://doi.org/10.1053/.jgastro.2018.03.022.

29. Belli LS, Berenguer M, Cortesi PA, Strazzabosco M, Rockenschaub SR, Martini $\mathrm{S}$, et al. Delisting of liver transplant candidates with chronic hepatitis $C$ after viral eradication: a European study. J Hepatol. 2016;65(3):524-31. https://doi. org/10.1016/j.jhep.2016.05.010.

30. Fernandez Carrillo C, Lens S, Llop E, Pascasio JM, Crespo J, et al. Treatment of hepatitis $C$ virus infection in patients with cirrhosis and predictive value of model for end-stage liver disease: analysis of data from the Hepa-C registry. Hepatology. 2017;65(6):1810-22. https://doi.org/10.1002/hep.29097.

31. Terrault NA, McCaughan GW, Curry MP, Gane E, Fagiuoli S, et al. International liver transplantation society consensus statement on hepatitis C management in liver transplant candidates. Transplantation. 2017;101(5): 945-55. https://doi.org/10.1097/TP.0000000000001708.

32. Gentile I, Scotto R, Coppola C, Staiano L, Amoruso DC, de Simone T, et al. Treatment with direct-acting antivirals improves the clinical outcome in patients with HCV-related decompensated cirrhosis: results from an Italian real-life cohort (Liver Network Activity-LINA cohort). Hepatol Int. 2019;13(1): 66-74. https://doi.org/10.1007/s12072-018-9914-6.

33. Curry MP, O'Leary JG, Bzowej N, et al. Sofosbuvir and velpatasvir for HCV in patients with decompensated cirrhosis. N Engl J Med. 2015;373(27):2618-28. https://doi.org/10.1056/NEJMoa1512614.

34. Domínguez Domínguez L, Matarranz M, Lagarde M, Bisbal O, Hernando A, Lumbreras $C$, et al. HCV eradication with all-oral therapy in cirrhotic HIVcoinfected patients: an observational study of early changes in liver function and fibrosis tests. Rev Esp Enferm Dig. 2019;111(8):626-32. https://doi.org/1 0.17235/reed.2019.6086/2018.

35. Flisiak R, Janczewska E, Łucejko M, Karpińska E, Zarębska-Michaluk D, Nazzal $\mathrm{K}$, et al. Durability of virologic response, risk of de novo hepatocellular carcinoma, liver function and stiffness 2 years after treatment with ombitasvir/paritaprevir/ritonavir \pm dasabuvir \pm ribavirin in the AMBER, realworld experience study. J Viral Hepat. 2018;25(11):1298-305. https://doi. org/10.1111/jvh.12945.

36. Lens S, Alvarado-Tapias E, Mariño Z, Londoño MC, LLop E, Martinez J, et al. Effects of all-oral anti-viral therapy on HVPG and systemic hemodynamics in patients with hepatitis C virus-associated cirrhosis. Gastroenterology. 2017; 153(5):1273-83. https://doi.org/10.1053/.gastro.2017.07.016.

37. Pons M, Rodríguez-Tajes S, Esteban Jl, Mariño Z, Vargas V, Lens S, et al. Noninvasive prediction of liver-related events in patients with HCV-associated compensated advanced chronic liver disease after oral antivirals. J Hepatol. 2020;72(3):472-80. https://doi.org/10.1016/j.jhep.2019.10.005.

\section{Publisher's Note}

Springer Nature remains neutral with regard to jurisdictional claims in published maps and institutional affiliations.

\section{Ready to submit your research? Choose BMC and benefit from:}

- fast, convenient online submission

- thorough peer review by experienced researchers in your field

- rapid publication on acceptance

- support for research data, including large and complex data types

- gold Open Access which fosters wider collaboration and increased citations

- maximum visibility for your research: over $100 \mathrm{M}$ website views per year

At BMC, research is always in progress.

Learn more biomedcentral.com/submissions 